\title{
Study on the torrential catfish Amblyceps apangi Nath \& Dey 1989 (Teleostei: Amblycipitidae) from Wokha district, Nagaland
}

\author{
L. Nzano Humtsoe ${ }^{1} \&$ Sabitry Bordoloi ${ }^{2}$ \\ 1,2 Resource Management and Environment Division, Institute of Advanced Study in Science and Technology, Paschim Boragaon, \\ Guwahati, Assam 781035, India \\ Email: ${ }^{2}$ sabitrybordoloi@ rediffmail.com (corresponding author)
}

Date of online publication 26 February 2009 ISSN 0974-7907 (online) | 0974-7893 (print)

Editor: W. Vishwanath

\section{Manuscript details:}

Ms \# 01815

Received 28 June 2007

Final revised received 06 December 2007

Finally accepted 21 February 2008

Citation: Humtsoe, L.N. \& S. Bordoloi (2009) Study on the torrential catfish Amblyceps apangi Nath \& Dey 1989 (Teleostei: Amblycipitidae) from Wokha district, Nagaland. Journal of Threatened Taxa 1(2): 109-113.

Copyright: (C) L.N. Humtsoe \& S. Bordoloi 2009. Creative Commons Attribution 3.0 Unported License. JoTT allows unrestricted use of this article in any medium for nonprofit purposes, reproduction and distribution by providing adequate credit to the authors and the source of publication.

Author details: L. NZANO HUMtSOE is persuing her doctoral work under the supervision and guidance of $\operatorname{Dr}(\mathrm{Mrs})$. Sabitry Choudhury Bordoloi. She is working as a Junior Research Fellow with RGNFS of U.G.C.

SABITRY Bordolol, Heads the Resource Management and Environment Division of Institute of Advanced Study in Science and Technology, Paschim Boragaon, Guwahati, Assam, India.

Author contribution: LNH has conducted the field work and SB is the PhD guide and corresponding author.

Acknowledgements: Authors express their gratitude to U.G.C. for awarding Rajiv Gandh National Fellowship to L.N. Humtsoe to carry out the survey work.

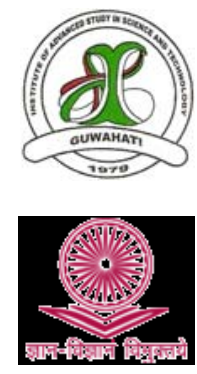

OPEN ACCESS | FREE DOWNLOAD
Abstract: Streams of Wokha district, Nagaland were surveyed (2005-2006) to document the torrential fish fauna. Amblyceps apangi Nath \& Dey (1989) was collected from seven of the 12 streams surveyed, and found to be abundant in those streams. Detailed description of the study area, habitat characteristics of the streams, habitat ecology of the fish and a morphological study (based on 20 males and 20 females), is discussed.

Keyword: Amblyceps apangi, distribution, ecology.

\section{INTRODUCTION}

Three species of the genus Amblyceps Blyth have been recorded from the North Eastern region of India in the Brahmaputra drainage (Choudhuri 1913; Jayaram \& Mazumdar 1964; Choudhury \& Sen 1977; Nath \& Dey 1989; Ng 2005). They are Amblyceps apangi Nath \& Dey (1989), Amblyceps arunachalensis Nath \& Dey (1989) and Amblyceps mangois Hamilton (1822). Nath and Dey first described Amblyceps apangi and Amblyceps arunachalensis as new species on the basis of three specimens each from Dikrong river, Arunachal Pradesh, India. Ng (2005) synonymised Amblyceps arunachalensis with Amblyceps mangois. Vishwanath and Linthoingambi (2007) redescribed Amblyceps apangi and Amblyceps arunachalensis and resurrected Amblyceps arunachalensis from synonymy with Amblyceps mangois.

Survey of torrential hill streams from Wokha district have been carried out since August 2005. Two species of torrential catfish of the genus Amblyceps Blyth have been recorded from the streams: Amblyceps apangi and A. arunachalensis. Amblyceps apangi has been recorded from most of the streams in good numbers, while $A$. arunachalensis was found to be rare and only one specimen was collected from one stream.

Two specimens of Amblyceps apangi were earlier recorded from Dikhu river, Mokokchung district, Nagaland (Vishwanath \& Linthoingambi 2007).

So far we have collected 245 samples and recorded fish up to the size of $156.5 \mathrm{~mm}$ (male specimen). The present study of the species Amblyceps apangi Nath \& Dey, collected from hill streams of Wokha district has been carried out with a description based on Nath \& Dey (1989) and Vishwanath \& Linthoingambi (2007). Morphological parameters were derived from male and female specimens $(n=20)$.

\section{Methods}

Twelve hill streams were selected for study and sampling was conducted during premonsoon, monsoon and post-monsoon periods. Water quality of the streams was monitored for two years (Table 1). Fish were collected from the hill streams, narcotized with chloroform and then preserved in $6 \%$ formaldehyde solution. Measurements were taken with dial vernier calliper to the nearest third decimal. Detailed morphological description is in conformity with those given by Nath \& Dey (1989) and Vishwanath \& Linthoingambi (2007). Sex was determined by dissecting the specimens. Tables $2-5$ provide the summary of morphometric data.

\section{Description of study area}

Wokha district $\left(25^{\circ} 55^{\prime}-26^{\circ} 35^{\prime} \mathrm{N} \& 94^{\circ} 10^{\prime}-94^{\circ} 25^{\prime} \mathrm{E}\right)$ of Nagaland state $\left(25^{\circ} 15^{\prime}-27^{\circ} 04^{\prime} \mathrm{N}\right.$ \& $93^{\circ} 20^{\prime}-95^{\circ} 15^{\prime} \mathrm{E}$ ) of northeastern India has an altitude of $1313.69 \mathrm{~m}$. Its hilly terrain is traversed by numerous torrential hill streams that flow into the Doyang river, a major tributary of the river Brahmaputra. The Doyang river divides Wokha into two regions: a northern plain region called Lio Wokha and a southern hilly region called Nrung 
Table 1. Physico-chemical parameters of the 12 streams (after APHA 1998)

\begin{tabular}{|c|c|c|c|c|c|c|c|}
\hline & Streams & $\begin{array}{l}\text { Water } \\
\text { temperature }{ }^{\circ} \mathrm{C}\end{array}$ & $\mathrm{pH}$ & $\begin{array}{l}\text { Dissolved } \\
\text { oxygen Mg/l }\end{array}$ & $\begin{array}{l}\text { Free } \\
\mathrm{CO}_{2} \mathrm{Mg} / \mathrm{l}\end{array}$ & $\begin{array}{l}\text { Total } \\
\text { alkalinity } \mathrm{Mg} / \mathrm{l}\end{array}$ & $\begin{array}{l}\text { Hardness } \\
\text { Mg/l }\end{array}$ \\
\hline 1 & Lungkitchu & $7.8-18^{\circ} \mathrm{C}$ & $6.5-8.5$ & $7.2-13.6$ & $4-8$ & $38-60$ & 53-115 \\
\hline 2 & Nhyatsutchu & 8-19.2 & $6.5-8.5$ & $7.6-15.2$ & $4-8$ & $38-60$ & $57-112$ \\
\hline 3 & Kyotchu & 8-19.6 & $6.5-8.5$ & $7.6-14$ & $4-8$ & $42-60$ & $58-105$ \\
\hline 4 & Engorotchu & $7.8-19.6$ & $6.5-8.5$ & $7.2-13.6$ & $4-8$ & $46-60$ & $53-106$ \\
\hline 5 & Nitsutchu & $7.4-19.2$ & $6.5-8.5$ & $7.2-14$ & $4-8$ & $38-60$ & $56-110$ \\
\hline 6 & Tchulumo & $12.4-25.8$ & $6.5-8.5$ & $7.6-14.8$ & $4-8$ & $40-62$ & $51-92$ \\
\hline 7 & Tsupvu & $8.2-25$ & $6.5-8.5$ & $8-15.2$ & $4-8$ & $46-68$ & $54-102$ \\
\hline 8 & Humtso Tsupvu & $12-26$ & $6.5-8.5$ & $8-15.6$ & $4-8$ & $42-64$ & $57-102$ \\
\hline 9 & Sosurotchu & $8.2-25$ & $6.5-8.5$ & $7.2-14.4$ & $4-8$ & $38-60$ & $50-102$ \\
\hline 10 & Vekhvurotchu & $12-25$ & $6.5-8.5$ & $7-12.8$ & $6-8$ & $48-60$ & $48-89$ \\
\hline 11 & Yikhum Sanga & $8.2-24$ & $6.5-8.5$ & $7.2-13.2$ & $6-8$ & $40-64$ & $56-105$ \\
\hline 12 & Tsurang & $13.6-28$ & $6.5-8.5$ & $7.6-14.4$ & $4-8$ & $52-70$ & 53-101 \\
\hline
\end{tabular}

Wokha. Mt. Tiyi (altitude 1969m) is the highest peak in Wokha district and is situated at Nrung Wokha; many torrential streams originate from this mountain range and traverse the Nrung area.

The topography of Lio and Nrung differ. Nrung is hilly with a cool and moderate climate, temperatures seldom exceed $28^{\circ} \mathrm{C}$. Lio is less hilly with low lying areas and plains, the climate is hot and humid and temperature sometimes exceed $33^{\circ} \mathrm{C}$. Lio shares its border with Assam.

\section{Streams selected for study}

12 streams were selected for study. The streams surveyed are along the NH61 (Wokha-Mokokchung road) and along Wokha-Merapani road in Nrung area and Tsurang river, a tributary of Doyang river in Lio region. All the streams flow into the Doyang river, some drain directly while some smaller streams join other tributaries of the Doyang and then flow into the Doyang river. The Doyang river finally joins the Brahmaputra river of Assam. Thus the streams of Wokha belong to the Brahmaputra drainage.

Streams along the NH61 (Wokha-Mokokchung road), Nrung: 1. Engorotchu, 2. Kyotchu, 3. Lungkitchu, 4. Nhyatsutchu, 5. Nitsutchu, 6. Tchulumo, 7. Tsupvu.

Streams along Wokha-Merapani road: 1. Humtso Tsupvu, 2. Sosurotchu, 3. Vekhvurotchu, 4. Yikhum Sanga.

Stream surveyed in Lio area: 1 . Tsurang river.

Habitat characteristics of the streams/Nature of the streams: All the streams are of mountain origin, highly torrential, flowing through hilly terrain and cultivated lands. The streams are mostly shallow but deep in some areas and the water is crystal clear. The stream beds are rocky and occasionally muddy. Submerged vegetation, rocks, boulders, steep waterfalls, rapids and pools are characteristics of all the streams.

Water quality: Physico- chemical parameters of the streams were monitored for 2 years. Ecological parameters such as water temperature, $\mathrm{pH}, \mathrm{DO}$, free carbon dioxide, total alkalinity and hardness of water were recorded. Table-1 shows the physicochemical parameters of 12 streams recorded during 2 years study period.

Distribution of Amblyceps apangi in northeastern India: Arunachal Pradesh, Nagaland: Brahmaputra basin.

During the study period all 12 streams were surveyed. Amblyceps apangi was recorded from seven streams: Kyotchu,
Nhyatsutchu, Nitsutchu, Humtso Tsupvu, Sosurotchu, Vekhvurotchu and Yikhum Sanga. Amblyceps arunachalensis was recorded from the Tsurang river only. Amblyceps apangi was found to be abundant in the streams from where they were recorded, while Amblyceps arunachalensis was found to be very rare and recorded only once from Tsurang river.

\section{Taxonomic description of Amblyceps apangi Nath \& Dey}

Type locality: 3 specimens -2 males and 1 female from Dikrong river, Arunachal Pradesh, India (Nath \& Dey 1989); redescribed by Vishwanath \& Linthoingambi (2007) based on 11 specimens collected from Arunachal Pradesh and 2 specimens collected from Nagaland (compared with Nath \& Dey's collection). Present collection (245 samples) from wokha district, Nagaland, in Institute of Advanced Study in Science and Technology (IASST) museum.

Diagonosis: Jaws sub-equal, upper jaw slightly longer than lower jaw; rictal folds large and very well developed; skin smooth, pinnate-like folds absent; adipose dorsal fin not confluent with caudal fin, but placed very closely appearing to be confluent; caudal fin truncate; lateral line present, straight, complete (Nath \& Dey 1989; Vishwanath \& Linthoingambi 2007 ).

Body description: Body long, slender, sub-cylindrical, getting compressed posteriorly, abdomen rounded; head narrow and depressed, dorso-ventrally flattened, covered with thick skin; nostrils close together; eyes small, almost indistinguishable, subcutaneous; mouth terminal, upper jaw slightly longer than lower jaw; lips thick and fleshy, rictal folds very well developed, its upper and lower lobe continues to basal part of maxillary barbel on each side; teeth in upper jaw in broad band with posterior extensions on both sides and separated by a very narrow gap, those in lower jaw a semicircular band, separated in the middle; prominent fold of skin (cup-like) present posterior to opercular flap and in front of pectoral fin in which the gill membrane rests when the gill openings are closed.

Images 1-4 show the morphological structure of $A$. apangi. Image 5 shows $A$. arunachalensis collected from Tsurang river. Figure 1 The map of Wokha district showing sampling sites.

Barbels: four pairs, 1 pair each of maxillary and nasal and 2 pairs of mandibular; maxillary barbel is the longest and reaches beyond posterior base of pectoral fin.

Fins: D ii 5-6; A ii-iii 7; P I 16; V I 5; C 7+7. Dorsal fin rayed, without spine, originates vertically through middle 


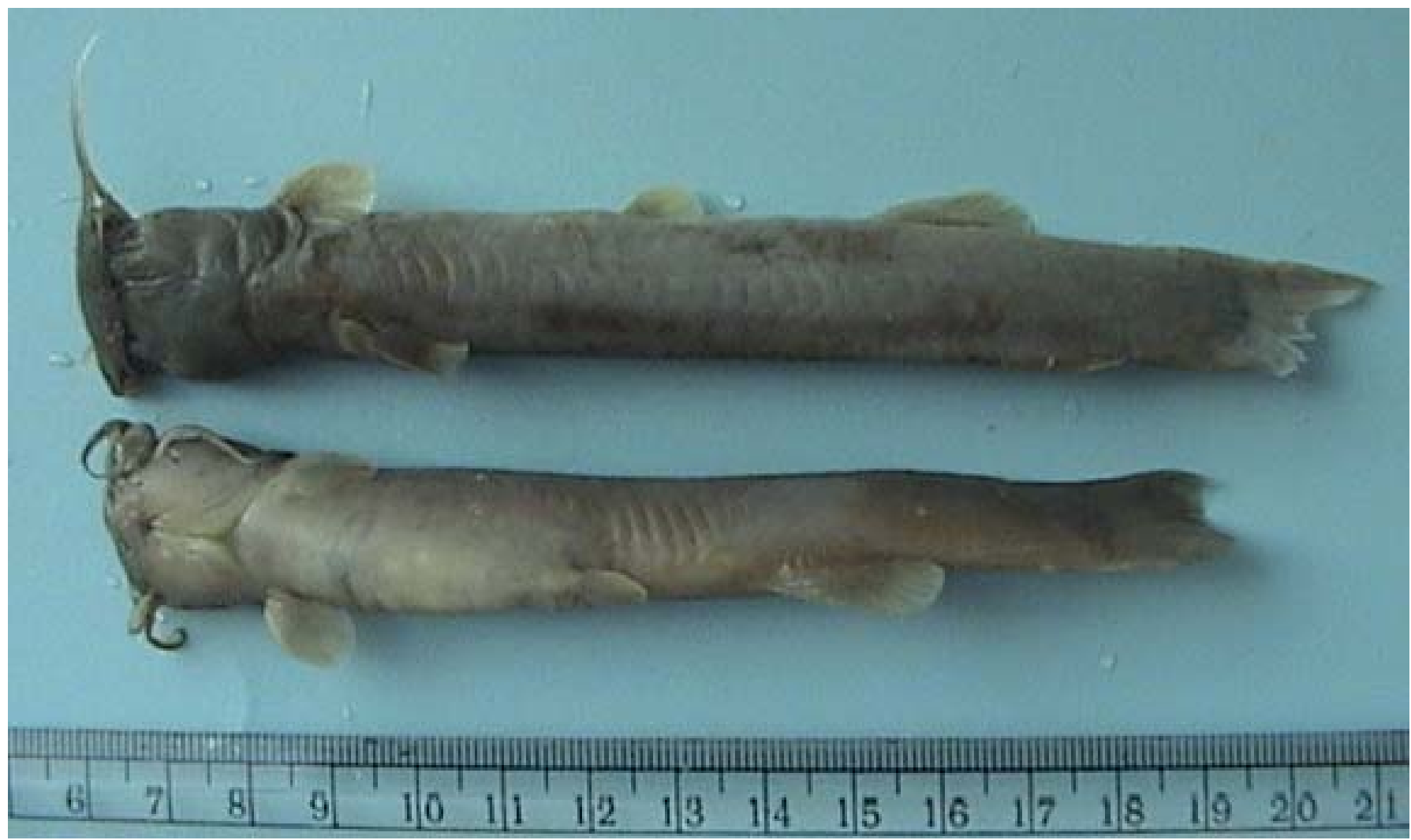

Image 1. Dorsal and ventral surface of Amblyceps apangi

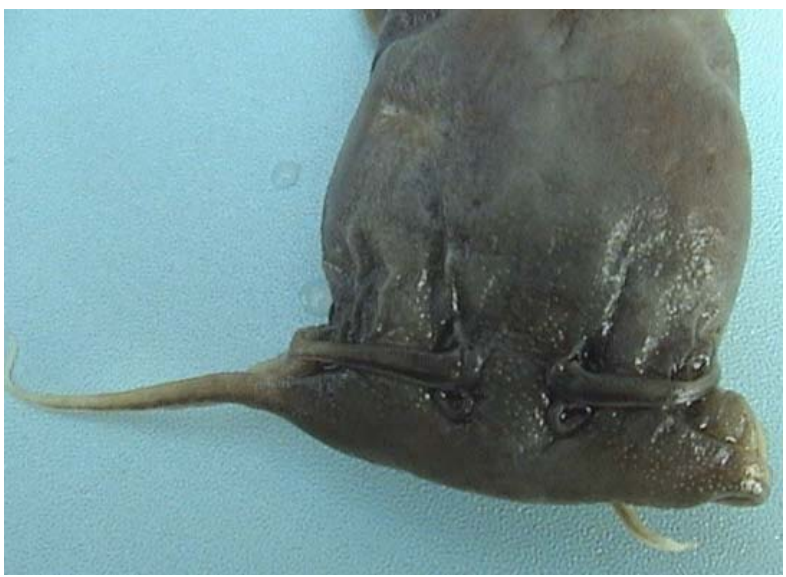

Image 2. Head dorsal of Amblyceps apangi

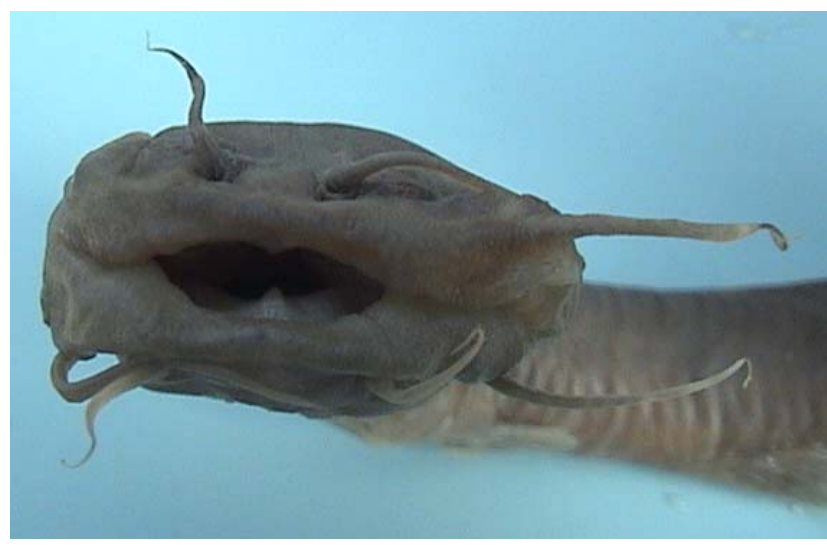

Image 4. Mouth of Amblyceps apangi

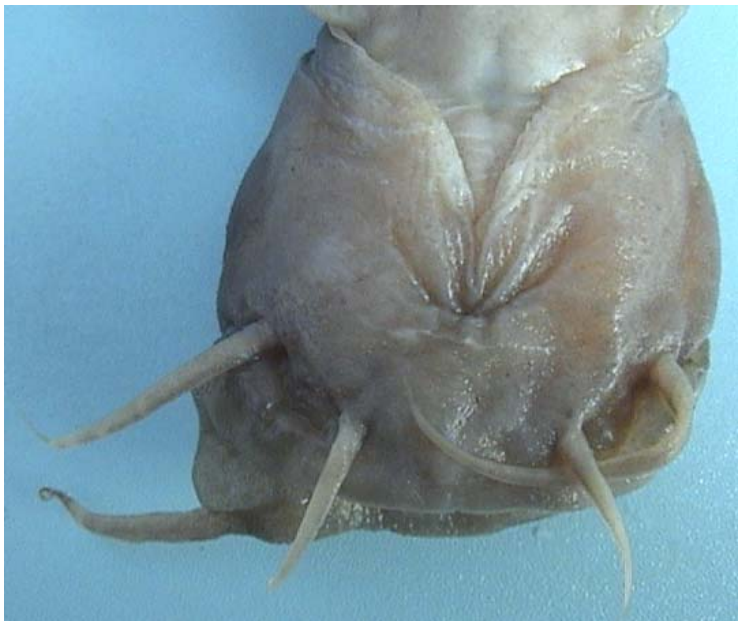

Image 3. Head ventral of Amblyceps apangi

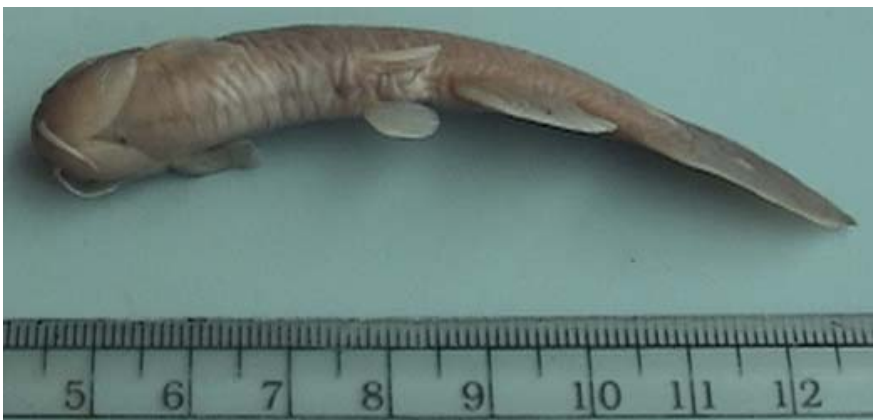

Image 5. A. arunachalensis ventral - collected from Tsurang river. 
Table 2. Morphometric characters of female in \% SL except $\mathrm{SL}$ given in $\mathrm{mm}$

\begin{tabular}{lllllll}
\hline S.no & Characters & Min & Max & Ave & SD & $\begin{array}{l}\text { SE of } \\
\text { SD }\end{array}$ \\
& & & & & & \\
\hline 1 & Standard length & 45.25 & 128.8 & 76.445 & 20.59 & 3.25 \\
2 & Body depth at dorsal origin & 10.27 & 14.4 & 12.8 & 1.27 & 0.2 \\
3 & Body width at anal origin & 5.07 & 8.68 & 6.7 & 1.08 & 0.17 \\
4 & Head depth & 8.58 & 12.86 & 10.58 & 1.025 & 0.16 \\
5 & Head length & 20.11 & 22.54 & 21.32 & 0.77 & 0.12 \\
6 & Head width & 14.02 & 17.16 & 15.63 & 0.74 & 0.11 \\
7 & Eye diameter & 0.69 & 1.76 & 1.14 & 0.27 & 0.04 \\
8 & Snout length & 6.33 & 9.07 & 7.95 & 0.73 & 0.11 \\
9 & Inter-orbital width & 3.74 & 7.29 & 5.46 & 0.94 & 0.14 \\
10 & Pre-dorsal length & 22.88 & 25.8 & 24.39 & 0.86 & 0.13 \\
11 & Post-dorsal length & 30.55 & 39.58 & 34.87 & 2.37 & 0.37 \\
12 & Pre-pelvic distance & 46.74 & 51.77 & 48.9 & 1.35 & 0.21 \\
13 & Length of dorsal fin & 11.6 & 19.66 & 14.46 & 2.11 & 0.33 \\
14 & Length of dorsal fin base & 6.18 & 8.5 & 7.14 & 0.64 & 0.1 \\
15 & Length of adipose dorsal fin & 12.61 & 20.73 & 17.62 & 2.46 & 0.38 \\
16 & Length of base of anal fin & 11.72 & 15.13 & 13.5 & 0.83 & 0.13 \\
17 & Length of pectoral fin & 10.2 & 14.15 & 12.01 & 1.15 & 0.18 \\
18 & Length of pelvic fin & 7.33 & 10.93 & 8.83 & 1.02 & 0.16 \\
19 & Depth of caudal peduncle & 11.25 & 15.35 & 12.97 & 0.82 & 0.13 \\
20 & Length of caudal peduncle & 19 & 22.43 & 20.78 & 0.98 & 0.15 \\
21 & Length of longest fin ray & 14.2 & 19 & 16.57 & 1.21 & 0.19 \\
& & & & & & \\
\hline
\end{tabular}

Min - Minimum; Max - Maximum; Ave - Average; SD - Standard Deviation; SE of SD - Standard Error of Standard Deviation

Table 4. Morphometric characters of male in \% SL except $\mathrm{SL}$ given in $\mathrm{mm}$

\begin{tabular}{|c|c|c|c|c|c|c|}
\hline S.no & Characters & Min & Max & Ave & SD & $\begin{array}{l}\text { SE of } \\
\text { SD }\end{array}$ \\
\hline 1 & Standard length & 51.65 & 135.5 & 88.269 & 19.547 & 3.09 \\
\hline 2 & Body depth at dorsal origin & 11.53 & 15.26 & 13.29 & 0.957 & 0.151 \\
\hline 3 & Body width at anal origin & 5.12 & 9 & 6.58 & 1.039 & 0.164 \\
\hline 4 & Head depth & 9.2 & 12.9 & 10.69 & 1.071 & 0.169 \\
\hline 5 & Head length & 20.41 & 22.63 & 21.67 & 0.733 & 0.116 \\
\hline 6 & Head width & 15.34 & 18.95 & 16.58 & 0.905 & 0.143 \\
\hline 7 & Eye diameter & 0.66 & 1.54 & 1.009 & 0.22 & 0.034 \\
\hline 8 & Snout length & 7.45 & 9.31 & 8.12 & 0.449 & 0.071 \\
\hline 9 & Inter-orbital width & 4.1 & 5.78 & 4.76 & 0.473 & 0.074 \\
\hline 10 & Pre-dorsal length & 23.82 & 26.83 & 25.45 & 0.706 & 0.111 \\
\hline 11 & Post-dorsal length & 29.42 & 40.77 & 34.003 & 2.816 & 0.445 \\
\hline 12 & Pre-pelvic distance & 46.57 & 52.33 & 48.93 & 1.24 & 0.196 \\
\hline 13 & Length of dorsal fin & 12.27 & 16.76 & 13.57 & 1.445 & 0.228 \\
\hline 14 & Length of dorsal fin base & 6.09 & 8.88 & 7.28 & 0.675 & 0.106 \\
\hline 15 & Length of adipose dorsal fin & 16.94 & 24.17 & 21.18 & 2.216 & 0.35 \\
\hline 16 & Length of base of anal fin & 12.32 & 16.19 & 13.51 & 0.861 & 0.136 \\
\hline 17 & Length of pectoral fin & 10.47 & 13.16 & 11.54 & 0.699 & 0.11 \\
\hline 18 & Length of pelvic fin & 7.78 & 10.31 & 8.71 & 0.67 & 0.106 \\
\hline 19 & Depth of caudal peduncle & 11.43 & 14.99 & 13.3 & 0.819 & 0.129 \\
\hline 20 & Length of caudal peduncle & 18.68 & 23.19 & 21.37 & 1.393 & 0.22 \\
\hline 21 & Length of longest fin ray & 12.91 & 18.67 & 15.93 & 1.178 & 0.186 \\
\hline
\end{tabular}

Min - Minimum; Max - Maximum; Ave - Average; SD - Standard Deviation; SE of SD - Standard Error of Standard Deviation

length of pectoral fin; origin of adipose fin is at the level of posterior base of anal fin; adipose fin continues up to caudal fin but is not confluent with it; pectoral fins extend up to the level of middle of dorsal fin; caudal fin truncate, second outer branched rays in upper and lower lobe longest; all paired and unpaired fins covered by a thin membrane. Lateral line present, complete, straight, with tubular openings; pores arranged in pairs, each pair separated by a short gap.

Sexual dimorphism: There is no clear sexual dimorphism observed between male and female except for minor structural variations between the sexes. Total length of male ranges from 59.3 to $156.5 \mathrm{~mm}$ and in female 52.8 to $146.6 \mathrm{~mm}$, and
Table3. Morphometric characters of female in \% HL except $\mathrm{HL}$ given in $\mathrm{mm}$

\begin{tabular}{lllllll}
\hline S.no & Characters & Min & Max & Ave & SD & $\begin{array}{l}\text { SE of } \\
\text { SD }\end{array}$ \\
\hline 1 & Head length & 10.2 & 79.57 & 16.2 & 3.98 & 0.62 \\
2 & Standard length & 443.62 & 497.23 & 469.51 & 17.06 & 2.69 \\
3 & Body depth at dorsal origin & 48.37 & 70.47 & 60.07 & 6.02 & 0.95 \\
4 & Body width at anal origin & 24.2 & 42.51 & 31.41 & 4.68 & 0.74 \\
5 & Head depth & 40.92 & 57.07 & 49.66 & 4.63 & 0.73 \\
6 & Head width & 66.67 & 7.84 & 73.37 & 3.88 & 0.61 \\
7 & Eye diameter & 3.44 & 40.74 & 5.34 & 1.13 & 0.17 \\
8 & Snout length & 31.49 & 32.35 & 37.27 & 2.81 & 0.44 \\
9 & Inter-orbital width & 17.86 & 120.84 & 25.54 & 3.92 & 0.62 \\
10 & Pre-dorsal length & 104.76 & 181.88 & 114.53 & 5.22 & 0.82 \\
11 & Post-dorsal length & 143.66 & 244.3 & 163.61 & 10.99 & 1.737 \\
12 & Pre-pelvic distance & 220.05 & 87.25 & 229.52 & 7.53 & 1.19 \\
13 & Length of dorsal fin & 56.06 & 38.12 & 67.72 & 8.66 & 1.36 \\
14 & Length of dorsal fin base & 30.06 & 38.12 & 33.48 & 2.42 & 0.38 \\
15 & Length of adipose dorsal fin & 57.25 & 97.23 & 82.9 & 12.88 & 2.03 \\
16 & Length of base of anal fin & 54.92 & 69.05 & 63.34 & 3.43 & 0.54 \\
17 & Length of pectoral fin & 48.72 & 62.83 & 56.28 & 4.29 & 0.67 \\
18 & Length of pelvic fin & 35.68 & 49.21 & 41.4 & 4.2 & 0.66 \\
19 & Depth of caudal peduncle & 55.44 & 68.13 & 60.81 & 2.86 & 0.45 \\
20 & Length of caudal peduncle & 86.08 & 109.75 & 97.6 & 5.75 & 0.91 \\
21 & Length of longest fin ray & 69.98 & 84.31 & 77.66 & 3.93 & 0.62 \\
\hline
\end{tabular}

Min - Minimum; Max - Maximum; Ave - Average; SD - Standard Deviation; SE of SD - Standard Error of Standard Deviation

Table 5. Morphometric data of male in \% HL except HL given in $\mathrm{mm}$

\begin{tabular}{lllllll}
\hline S.no & Characters & Min & Max & Ave & SD & $\begin{array}{l}\text { SE of } \\
\text { SD }\end{array}$ \\
\hline & & & & & & \\
1 & Head length & 11.5 & 30.2 & 19.12 & 4.34 & 0.68 \\
2 & Standard length & 441.7 & 489.93 & 461.94 & 15.96 & 2.52 \\
3 & Body depth at dorsal origin & 0.54 & 54.63 & 3.31 & 12.07 & 1.9 \\
4 & Body width at anal origin & 23.01 & 40.46 & 30.39 & 4.62 & 0.73 \\
5 & Head depth & 42.46 & 58.16 & 49.35 & 4.8 & 0.76 \\
6 & Head width & 69.73 & 84.88 & 76.58 & 4.21 & 0.66 \\
7 & Eye diameter & 2.98 & 6.95 & 4.66 & 0.99 & 0.15 \\
8 & Snout length & 33.44 & 43.19 & 37.5 & 2.24 & 0.35 \\
9 & Inter-orbital width & 18.81 & 26.84 & 21.99 & 2.06 & 0.32 \\
10 & Pre-dorsal length & 110.05 & 125.66 & 117.57 & 4.55 & 0.72 \\
11 & Post-dorsal length & 137.17 & 180.46 & 156.83 & 10.76 & 1.7 \\
12 & Pre-pelvic distance & 209.67 & 239.51 & 225.99 & 8.32 & 1.31 \\
13 & Length of dorsal fin & 54.83 & 76.26 & 62.66 & 6.5 & 1.02 \\
14 & Length of dorsal fin base & 28.57 & 40.22 & 33.62 & 3.2 & 0.5 \\
15 & Length of adipose dorsal fin & 78.47 & 115.04 & 97.92 & 11.34 & 1.79 \\
16 & Length of base of anal fin & 56.18 & 79.08 & 62.45 & 4.74 & 0.75 \\
17 & Length of pectoral fin & 47.01 & 62.74 & 53.32 & 3.87 & 0.61 \\
18 & Length of pelvic fin & 36.5 & 47.85 & 40.23 & 3.08 & 0.48 \\
19 & Depth of caudal peduncle & 51.32 & 73.2 & 61.5 & 4.66 & 0.73 \\
20 & Length of caudal peduncle & 84.81 & 106.61 & 98.71 & 6.57 & 1.04 \\
21 & Length of longest fin ray & 57.94 & 91.55 & 98.71 & 6.91 & 1.09 \\
\hline
\end{tabular}

Min - Minimum; Max - Maximum; Ave - Average; SD - Standard Deviation; SE of SD - Standard Error of Standard Deviation

standard length of male ranges from 51.65 to $135.5 \mathrm{~mm}$ and of female 42.25 to $128.8 \mathrm{~mm}$. No colour change occurs during breeding season.

\section{Habitat and ecology}

This catfish is found in fast-moving and torrential hill streams, and occasionally in slow moving ones. They inhabit places with rocky stream beds, rocks and boulders where they can hide. They are bottom dwellers, usually found buried under mud, stones and rocks. They are gregarious, found living with other hill stream fishes in same habitat; they are usually found at the part of the stream where sunlight is maximum. They are 




Figure 1. Map of Wokha district Nagaland

1 - Engorotchu; 2 - Kyotchu; 3 - Lungkitchu; 4 - Nhyatsutchu;

5 - Nitsutchu; 6 - Tchulumo; 7 - Tsupvu; 8 - Humtso Tsupvu;

9 -Sosurotchu; 10 - Vekhvurotchu; 11 - Yikhum Sanga; 12 - Tsurang

carnivorous in habit and feed on aquatic organisms in the streams such as crabs, prawns, earthworms and insect larvae (e.g. caddisfly, mayfly, stonefly, dragonfly).

Organisms living in fast-moving waters show typical adaptations, and Amblyceps apangi is considered a true hill stream fish since it shows various body characteristics adapted to life in fast-flowing water (Hora 1922). These characteristics include an elongated, sub-cylindrical and ventrally flattened body, smooth and thick skin, a well-developed mouth with thick, fleshy lips with well developed rictal folds that extend to the base of maxillary barbel; barbels moderately long, having thick and fleshy bases; eyes small, almost indistinguishable and subcutaneous; ventral fins placed horizontally; all fins enveloped in a thin membrane; fin bases soft and swollen; caudal peduncle long.

Biology: Breeding behaviour was monitored for two years. Observations show that the fish is a single breeder, breeding only once a year. Breeding period was found to start in the month of January till early August. The maturity of the gonads is as follows:

Maturing phase: Gonads start maturing from early January till mid February.

Mature phase: Gonads become fully mature from late February till early August. Fully ripe ova with gravid eggs are observed in the month of March, April, May, June, July and early August.

Spent phase: From mid August till October.

\section{Remarks}

Amblyceps apangi was originally described by Nath \& Dey (1989) based on three specimens (2 males and 1 female). The fish has been redescribed by Vishwanath \& Linthoingambi (2007) on the basis of 11 specimens. However, the number of males and females were not mentioned. The present paper gives detailed measurements of 20 males and 20 females. The fish do not exhibit structural variation in male and female. In the present study the fish has been recorded from seven of twelve streams and was found to be abundant in its habitat. The fish has been reported earlier from Mokokchung district only in Nagaland. The present habitats are found to be congenial for this fish. Amblyceps arunachalensis is very rare in the habitats surveyed and we could collect only one sample during the study period.

This fish species is considered a good medicinal fish and is used in the treatment of sores (mouth and tongue), rashes, measles, etc. The fishes are first salted, then wrapped in banana leaves and roasted or smoked in fire and given to the affected person; they are also salted and dried for later use.

\section{RefERENCES}

APHA (1998). Standard Method for Examination of Water and Waste Waters - $15^{\text {th }}$ edition. APHA, Washington D.C

Choudhuri, B.L. (1913). Zoological results of the Abor expedition (1911-1912). Fish. Records of the Indian Museum 243-258.

Choudhury, S. \& N. Sen (1977). On a collection of fish from Arunachal Pradesh with some new records. Newsletter of the. Zoological Survey of India 3(4): 217-233.

Hora, S.L. (1922). Structural modification in the fishes of mountain torrents. Records of Indian Museum 24: 46-58

Jayaram, K.C. (1999). The Freshwater Fishes of the Indian Region. Narendra Publishing House, New Delhi, $551 \mathrm{pp}$.

Nath, P. \& S.C. Dey (1989). Two new species of the genus Amblyceps Blyth from Arunachal Pradesh, India. Journal of Assam Science Society $32(1): 1-6$

Ng, H.H (2005). Amblyceps carnatum, a new species of hill stream catfish from Myanmar (Teleostei: Amblycipitidae). Raffles Bulletin of Zoology $53(2): 243-249$.

Talwar, P.K. \& A.G. Jhingran (1991). Inland Fishes of India and Adjacent Countries Vol. I \& II. Oxford Publishing Co. Pvt. Ltd. New Delhi, $\mathrm{xix}+1158 \mathrm{pp}$.

Vishwanath, W. \& I. Linthoingambi (2007). Redescription of catfishes Amblyceps arunachalensis Nath \& Dey and Amblyceps apangi Nath \& Dey (Teleostei: Amblycipitidae). Zoos' Print Journal 22(4): 26622664

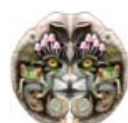

